\title{
NARROWLY - BOUNDED TURF IRRIGATION SYSTEM SELECTION USING "EXPERT SYSTEM" APPROACH
}

\author{
*Bedair, O. M.
}

\section{ABSTRACT}

Water scarcity in turf and landscape areas and increased water losses by using improper irrigation for narrow turf, or steep slopes cause design problems. Proper irrigation system selection for strips, islands, and areas near buildings, sidewalk, and steep areas is very important to obtain good turf quality, minimum operation, costs and water losses.

The objective of this study includes an expert system (ES) approach to assist proper choice for narrowly-bounded turf strips to get the best appearance and quality for different site conditions for qualifying resources. Results were validated by consultation with domain experts and knowledge available from literature, published research and pertinent experimentation to accommodate case studies using prepared and modified decision table. Six case studies (four actual: A, B, C, and D, and two virtual sites: $E$ and $F$ ) including extreme site conditions were used to test the proposed expert system for the proper selection of irrigation system from choices of irrigation systems. "Corvid Exsys" software program was designed to assist proper irrigation selection according to site conditions. The proposed ES and "Corvid Exsys" software were evaluated and tested on actual and virtual case studies, to assisted proper irrigation system selection for narrowly-bounded and sloped areas. The results of proposed ES on selected case studies and "Corvid Exsys" software outcomes were discussed. Results showed that the proposed software assist proper selection of irrigation system according to site conditions and resources including extreme conditions. The results showed that the subsurface drip irrigation system (SDI) gained the highest score by using case studies $(B, C, D$, and $E$ ) and in case study $(A$, and $F)$, multi-stream spray gained the highest score compared with other systems.

Keywords: Irrigation systems, Turf strips irrigation, Expert system, narrowly-bounded turf.

*Lecturer, Ag. Eng. Dep., Fac. Ag., Ain Shams U., Cairo, Egypt. 


\section{INTRODUCTION}

I n today's urban environments, there are many types of confined areas. They include a wide range of medians, islands or narrow strips of land near buildings, or sidewalks. A narrow strip of turf leads to significant quantities of water runoff, so careful planning and design can make these areas manageable. Awady, 2016, showed that Expert System (ES) approach can be efficiently used for best selection of appropriate system choice among different situations. Whittaker et al., 1987, reported that decision-making requires the use of expert knowledge; judgment and experience. Major steps and components that are involved in the complex process of building and developing of an (ES) were defined as: identification and software design; conceptualization formalization; implementation and validation of the program. Hillel, 2008, reported that the effects of wind, sprinkler overlap, and evapotranspiration can lead to application disuniformities which, in turn, can lead to excess water application. Drip irrigation has been used in horticultural operations since the middle of the $20^{\text {th }}$ century. There have been some investigations of the viability of using sub-surface drip irrigation (SDI) to irrigate turf grass ( Zoldoske et al., 1995; Leinauer and Makk, 2005; Johnson and Leinauer, 2004; Devitt and Miller, 1988; Ferguson, 1994) some of the benefits of SDI over conventional irrigation are that it operates at lower volumes and flow rates, puts water directly into the root zone, and is thus less susceptible to lessees from wind and evapotranspiration. Toro, 2006, reported that narrow or irregularly shaped areas, including turf, less than 8 feet in width in any direction, shall be irrigated with SDI or low volume water irrigation system. SDI saves water with minimal water loss due to mist, evaporation, runoff or wind drift. In addition, the amount of chemicals and fertilizer required to maintain the health of landscape is decreased, since these are applied directly at the root zone.

\section{MATERIAL AND METHODS}

The aim of this study is to assist in proper irrigation system selection for narrowly- bounded turf strips based on E.S. 
2.1 Engineering and hydraulic characteristics of turf irrigation systems:

The performance and required data of turf irrigation systems, under investigation, are presented in the following table (1):

Table (1): Engineering and hydraulic specification of turf irrigation systems under investigation.

\begin{tabular}{|l|c|c|c|c|}
\hline \multicolumn{1}{|c|}{ Irrigation sys. } & $\begin{array}{c}\text { Circle } \\
\text { Spray } \\
\text { (1) }\end{array}$ & $\begin{array}{c}\text { Rectangle } \\
\text { Spray } \\
\mathbf{( 2 )}\end{array}$ & $\begin{array}{c}\text { Multi- } \\
\text { stream } \\
\mathbf{( 3 )}\end{array}$ & $\begin{array}{c}\text { Sub- } \\
\text { surface drip } \\
\mathbf{( 4 )}\end{array}$ \\
\hline $\begin{array}{l}\text { Operating pressure } \\
\text { range(bar) }\end{array}$ & $1-3.0$ & $1.7-3.8$ & $2.1-3.8$ & $1-3.5$ \\
\hline Flow rate (m3/h) & $0.07-0.57$ & $0.04-0.12$ & $0.04-0.22$ & 0.0022 \\
\hline $\begin{array}{l}\text { Minimum infiltration } \\
\text { requirement (mesh) }\end{array}$ & $40-60$ & $70-80$ & $70-80$ & 120 \\
\hline Precip.R(mm/h) & $54-57$ & $6.7-8.7$ & $21-25$ & 7.8 \\
\hline Radius coverage (m) & $0.6-3.5$ & $\begin{array}{c}1.1 * 4.2- \\
1.8 * 9.9\end{array}$ & $2.6-3.5$ & $0.3-0.6$ \\
\hline DU\% & $50-60$ & $45-55$ & 80 & 95 \\
\hline
\end{tabular}

Data in the table (1) are according to Hunter, Rain Bird, 2017.

2.2 Actual site conditions and hypothetical areas under investigation, including engineering and hydraulic criteria of irrigation system:

Study areas were conducted in the Cairo governorate, Egypt. The latitude and longitude of the site are $30.0206857 \mathrm{~N}, 31.4419913 \mathrm{E}$ for "Lake View" residential, 30.032517 N, 31.530409 E for "Mountain View" residential, $30.025772 \mathrm{~N}, 31.445462 \mathrm{E}$ for "Villa", and $30.213209 \mathrm{~N}$, 31.683102 E for "Stalla, Misr- El Gdida" residential district respectively.

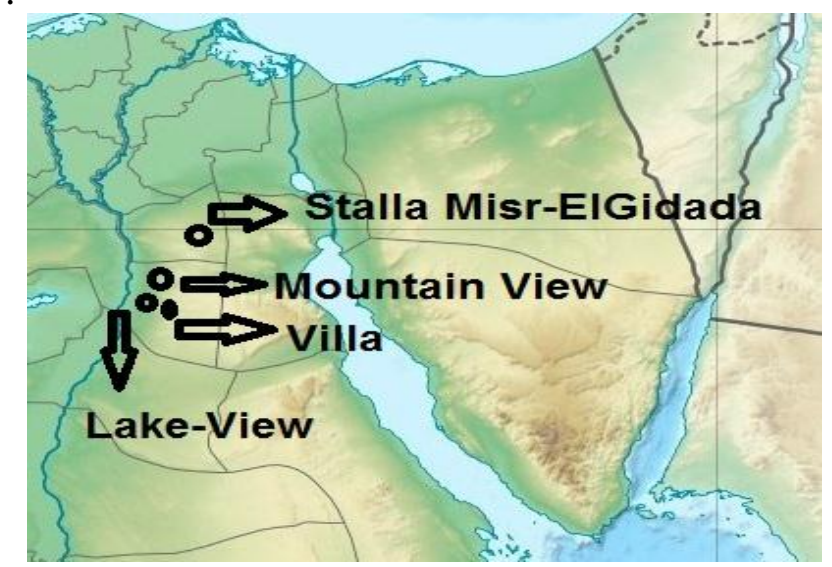

Fig. (1): Locations of actual cases under study. 


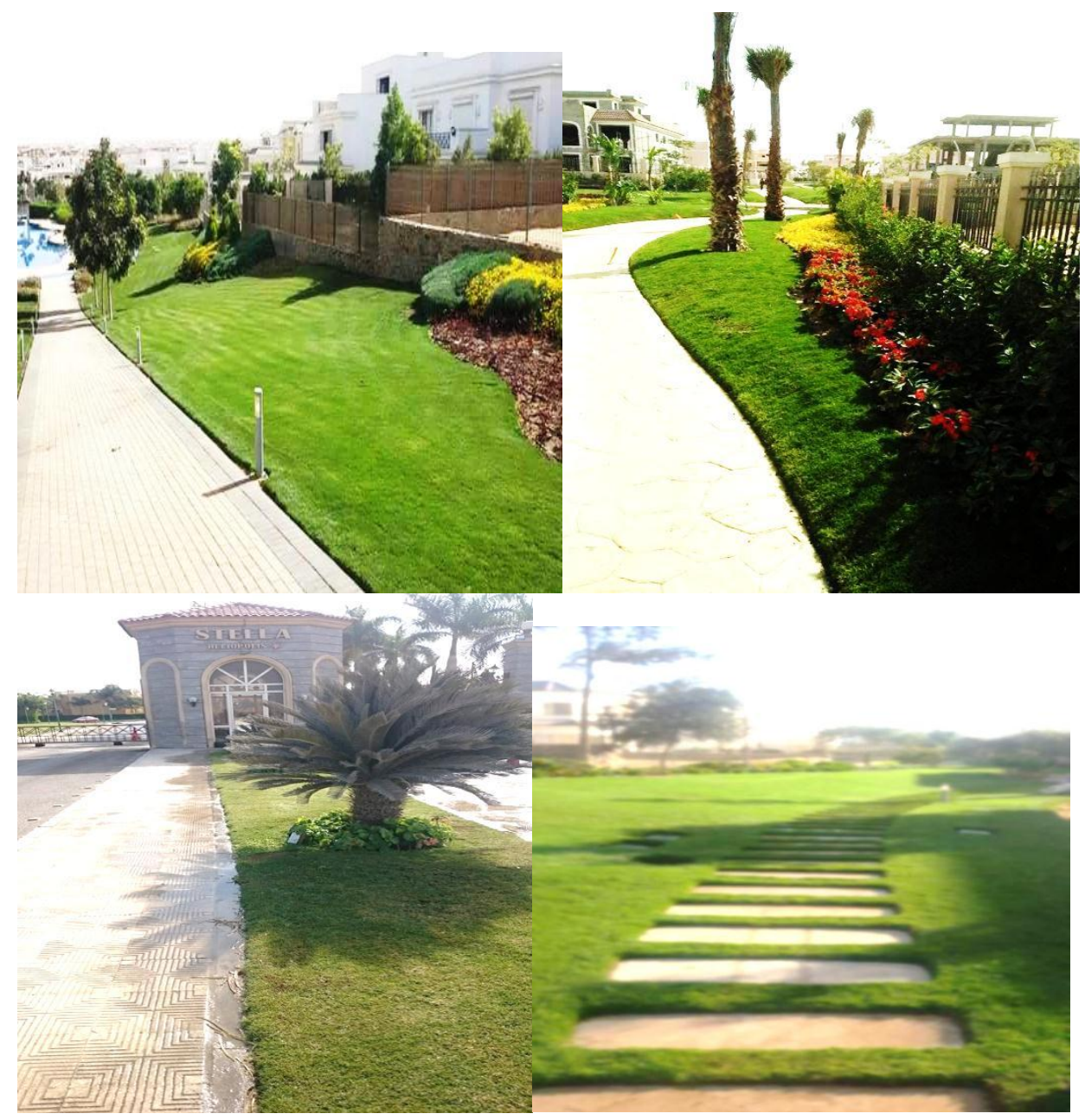

Fig. (2): Actual narrowly-bounded strip and sloped areas photos.

Table (2) shows site conditions and hypothetical areas under investigation including engineering and hydraulic criteria of irrigation systems. Four different representative sites and conditions including extreme cases with different resources and conditions, named case A, B, C, D (actual sites), and two case E, F(virtual sites) are shown in table(2).

\subsection{Procedure for the selection of the proper turf irrigation system:}

Decision table was prepared using methodology of Awady, 2016, with a committee of irrigation consultants and expertise, irrigation engineers and technical irrigation workers, to illustrate system choices and qualifier conditions to assist proper turf irrigation system selection for narrow strip areas. 
Table (2): Actual site conditions and virtual areas under investigation.

\begin{tabular}{|c|c|c|c|c|c|c|}
\hline \multirow[b]{3}{*}{ Site conditions } & \multicolumn{6}{|c|}{ Site and locations of cases under study } \\
\hline & $\begin{array}{c}{ }^{*} \text { Case } \\
\text { study (A) }\end{array}$ & $\begin{array}{c}\text { Case } \\
\text { study (B) }\end{array}$ & $\begin{array}{c}\text { Case } \\
\text { study } \\
(C) \\
\end{array}$ & $\begin{array}{c}\text { Case } \\
\text { study } \\
\text { (D) }\end{array}$ & $\begin{array}{c}\text { Case } \\
\text { study } \\
\text { (E) }\end{array}$ & $\begin{array}{c}\text { Case } \\
\text { study (F) }\end{array}$ \\
\hline & $\begin{array}{l}\text { New } \\
\text { Cairo } \\
\text { (Mountai } \\
\text { n view) }\end{array}$ & $\begin{array}{l}\text { New } \\
\text { Cairo } \\
\text { (Lake } \\
\text { view) } \\
\end{array}$ & $\begin{array}{l}\text { New } \\
\text { Cairo } \\
\text { (Villa) }\end{array}$ & $\begin{array}{c}\text { El- } \\
\text { Asher- } \\
\text { Misr- } \\
\text { Elgdida }\end{array}$ & (Virtu & I areas) \\
\hline $\begin{array}{l}\text { Total narrow } \\
\text { turf area } \\
\text { planted(m²) }\end{array}$ & 62000 & 400000 & 200 & 50000 & 1000 & 10000 \\
\hline Water source & $\begin{array}{c}\text { Recycled } \\
\text { water }\end{array}$ & $\begin{array}{c}\text { Recycled } \\
\text { water }\end{array}$ & $\begin{array}{c}\text { potable } \\
\text { water }\end{array}$ & $\begin{array}{l}\text { Well } \\
\text { water }\end{array}$ & $\begin{array}{c}\text { potable } \\
\text { water }\end{array}$ & $\begin{array}{c}\text { Well } \\
\text { water }\end{array}$ \\
\hline $\begin{array}{l}\text { Irrigation } \\
\text { system }\end{array}$ & $\begin{array}{l}\text { Multi- } \\
\text { stream }\end{array}$ & SDI & SDI & $\begin{array}{l}\text { Circle } \\
\text { Spray }\end{array}$ & $\begin{array}{l}\text { Rect. } \\
\text { spray }\end{array}$ & $\begin{array}{l}\text { Circle } \\
\text { Spray }\end{array}$ \\
\hline $\begin{array}{l}\text { Average strip } \\
\text { width range (m) }\end{array}$ & $1.5-3.5$ & $0.6-3$ & 2 & 2-3 & $0.6-1.5$ & $0.8-3$ \\
\hline $\begin{array}{l}\text { Average land } \\
\text { slope range } \%\end{array}$ & $0-10 \%$ & $0-15 \%$ & $0 \%$ & $0 \%$ & $0-20 \%$ & $0-25 \%$ \\
\hline $\begin{array}{l}\text { Area } \\
\text { consolidation }\end{array}$ & high & High & Low & Medium & Medium & High \\
\hline $\begin{array}{l}\text { Average wind } \\
\text { speed } \\
\text { range }(\mathrm{km} / \mathrm{h})^{\#}\end{array}$ & $0-5$ & $0-5$ & $0-5$ & $5-10$ & 15 & 10 \\
\hline $\begin{array}{l}\text { Filtration } \\
\text { system }\end{array}$ & $\begin{array}{l}\text { Media, } \\
\text { Screen }\end{array}$ & $\begin{array}{l}\text { Media, } \\
\text { Screen }\end{array}$ & Screen & Screen & Screen & Screen \\
\hline Feasibility & Moderate & Dense & Sparse & Dense & Sparse & Moderate \\
\hline
\end{tabular}

*Inhabited compound with turf green areas scattered among runway strips and buildings. The areas differ from as wide as $620000 \mathrm{~m}^{2}$ to as narrow as $1.5-3.5 \mathrm{~m}$ bounded small areas of only $6200 \mathrm{~m}^{2}$.

\# According to Central Laboratory of Agricultural Climate (CLAC).

Each case study had scores of confidence for each system, which reflect the suitability to the circumstances, table (3). Committee of five irrigation experts, four irrigation engineers in addition to three technicians and four project owners carried out consultations during seven meetings for about two hours/each to put an appropriate decision table for the proper selection of turf irrigation system, according to site conditions. The derived decision table is validated in actual and virtual case studies to test, 
and compare and agreement with the outcomes from derived decision table for all site conditions including extreme site conditions.

"Corvid Exsys" software program was used during consultant's committee ES, as tool for designers and technical users according to site conditions and resources in narrowly bounded, steep sloped areas.

Allotted weight of each qualifier was suggested according to experts' judgment by sorting qualifiers based on their importance and effectiveness on irrigation system selection. Each qualifier was given weight based on its effect on irrigation system selection among affected qualifier. This weight was multiplied times score for particular irrigation system (based on experts judgment) to get final score used to judge irrigation system appropriateness according to site conditions.

The qualifiers are represented in table (3), with final scores of irrigation systems under investigation, as discussed in the following:

1. Strip width suitability: was classified into three categories named (narrow- moderate- and wide), SDI system proves to be the most proper system for narrow strip areas compared to other systems. The lowest score was given to circular spray system in narrow strips.

2. Feasibility: Feasibility was categorized into three levels, according to density of narrow strip areas within the project area. The levels are named (dense plot- moderate density, and sparse plot). The highest score of 1.125 was given to SDI at dense plot level, and the lowest score of 0.25 was given to circular spray at the same level.

3. Water saving: water saving had weight of 1.0 ( referring to experts judgment) reflecting the effect of this qualifier on system selection multiplied times the score weight of water saving qualifier ( according to experts opinion) to get the score shown in table. 3

for irrigation systems under investigation, reflecting degree of system ability to save water. The more water saving gets highest score, and vice versa. For example, sub-surface drip (SDI) system had a score of 0.9 and circular spray system had a score of 0.45 .

4. Area consolidation: was classified into three categories named (lowmedium, and high) based on the ratios between small to project areas. The highest scores of $0.675,0.675$ were given to circular spray system and SDI system at high and low areas consolidation category, respectively. 
Table.3: Irrigation system scores based on experts judgment according to field conditions and allotted weights.

\begin{tabular}{|c|c|c|c|c|c|c|}
\hline \multirow{2}{*}{\multicolumn{2}{|c|}{ Qualifiers }} & \multirow{2}{*}{$\begin{array}{l}\text { *Allotted } \\
\text { weight }\end{array}$} & \multicolumn{4}{|c|}{ Inigation system choices } \\
\hline & & & $\begin{array}{l}\text { Circle } \\
\text { Spray }\end{array}$ & $\begin{array}{l}\text { Rect. } \\
\text { Spray }\end{array}$ & $\begin{array}{l}\text { Multi- } \\
\text { stream }\end{array}$ & SDI \\
\hline \multicolumn{7}{|c|}{ 1. * Strip width suitability } \\
\hline \multicolumn{2}{|c|}{ a. Narrow } & 1.5 & $\mathbf{0}$ & $\mathbf{0}$ & 0.75 & 1.425 \\
\hline \multicolumn{2}{|c|}{ b. Moderate } & 1.5 & 0.75 & 0.525 & 0.975 & 1.35 \\
\hline \multicolumn{2}{|c|}{ c. Wide } & 1.5 & 0.8 & 0.825 & 1.2 & 1.275 \\
\hline \multicolumn{7}{|c|}{ 2. Feasibility } \\
\hline \multicolumn{2}{|c|}{ a. Dense plot } & 1.25 & 0.25 & 0.375 & 0.875 & 1.125 \\
\hline \multicolumn{2}{|c|}{ b. Moderate density } & 1.25 & 1.125 & 0.937 & 0.562 & 0.25 \\
\hline \multicolumn{2}{|c|}{ c. Sparse plot } & 1.25 & 1.125 & 0.937 & 0.562 & 0.25 \\
\hline \multicolumn{2}{|c|}{ 3. Water saving } & 1.0 & 0.45 & 0.55 & 0.75 & 0.9 \\
\hline \multicolumn{7}{|c|}{ 4. Area consolidation } \\
\hline \multicolumn{2}{|c|}{ a. Low } & 0.75 & 0.187 & 0.15 & 0.337 & 0.675 \\
\hline \multicolumn{2}{|c|}{ b. Medium } & 0.75 & 0.45 & 0. 187 & 0.45 & 0.525 \\
\hline \multicolumn{2}{|c|}{ c. High } & 0.75 & 0.675 & 0.375 & 0.6 & 0.15 \\
\hline \multicolumn{7}{|c|}{ 5. Water quality } \\
\hline \multicolumn{2}{|r|}{ a. Reused water } & 0.6 & 0.39 & 0.39 & 0.33 & 0.15 \\
\hline \multicolumn{2}{|r|}{ b. Potable water } & 0.6 & 0.45 & 0.45 & 0.39 & 0.36 \\
\hline \multicolumn{2}{|r|}{ c. Well water } & 0.6 & 0.54 & 0.54 & 0.54 & 0.54 \\
\hline \multicolumn{7}{|c|}{ 6. Land slope } \\
\hline \multirow{7}{*}{$\stackrel{p}{\oplus}$} & a. Even land & 0.5 & 0.3 & 0.225 & 0.35 & 0.475 \\
\hline & b. Moderate level & 0.5 & 0.175 & 0.15 & 0.275 & 0.375 \\
\hline & c. Uneven land & 0.5 & 0.1 & 0.075 & 0.15 & 0.3 \\
\hline & 7. Wind losses & & & & & \\
\hline & a. Low & 0.4 & 0.26 & 0.22 & 0.3 & 0.4 \\
\hline & b. Medium & 0.4 & 0.2 & 0.16 & 0.22 & 0.4 \\
\hline & c. High & 0.4 & 0.16 & 0.12 & 0.18 & 0.4 \\
\hline \multicolumn{2}{|c|}{$\Sigma$} & 6.0 & & & & \\
\hline
\end{tabular}

- Allotted weight (according to experts' judgment), Max.=6.0

*Favorability of watering pattern to strip area.

5. Water quality: Clear water was given an equivalent score for all systems under choice. Low quality water was given the highest score for the highest clogging resistant systems.

6. Land slope: was classified based on land leveling into three categories, named (even land- moderate level - and uneven land). The 
highest score was given to low precipitation rate system to eliminate water losses due to runoff and deep percolation, specially with increasing land slope. SDI got score of 0.475 and multi-stream got a score of 0.35 for even land.

7. Wind losses: wind losses were classified into three categories, named (low- medium- and high) due to wind speed. Wind losses increased by increasing speed and vise versa.

The system resisting wind (wind losses) got the highest score and vise verse. Subsurface drip irrigation (SDI) had a score of 0.4 at high wind losses (high wind speed), multi-stream system score was 0.22 , or medium category.

\section{Allotted weight}

$\begin{array}{ll}\square \text { Wind losses } & \text { 鲁 Land slope } \\ \text { Water qauility } & \text { 四 Area consolidation } \\ \text { Water saving } & \text { Feasibilty } \\ \text { N Strip width } & \end{array}$

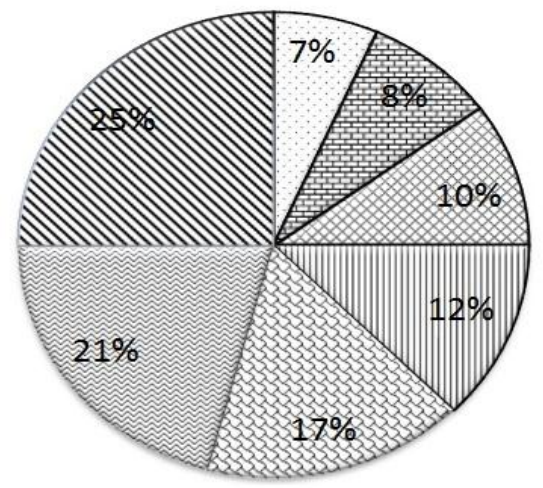

Fig.3: Qualifiers weight percent used for irrigation system appropriateness judgment.

\subsection{Irrigation system choices and qualifiers:}

Irrigation systems under investigation included: 1. Circular Spray 2. Rectangular spray 3.Multi-stream 4. Sub surface drip.

Score weights are given according to experts judgment as they affect irrigation- system selection among alternative actual conditions. Other virtual scores were collected to different choices according to different qualifiers. There assumption was based on experience and judgment of 
domain field engineering experts or extracted from literatures, such as (Omer et al., 2014). The highest irrigation system score gained from decision table was evaluated by experts to reach satisfaction results and agreement for outcomes to assist a proper selection according to site conditions.

\subsection{Validation and study cases:}

Six case studies (four actual named A, B, C, and D in addition to two virtual sites named $\mathrm{E}$ and $\mathrm{F}$ ) including extreme conditions were used to test the proposed ES for the proper selection of irrigation system from alternative choices of irrigation systems under investigation. Table 2 represents cases under study including conditions of each case. Cases were exposed to consultation with domain expert for validation of decision table. Each case of irrigation system was weighed under each suggested case. The manipulation of decision table was done using "Corvid Exsys" program, ver. 6.1.0 under windows 7 which was designed to include all qualifiers and site conditions, as shown in tables(3).

The highest score represents the most system appropriateness for the case study. The planning of "Corvid Exsys" program is shown in the following steps, to assist irrigation engineers, irrigation technicians, and owners to choose the proper irrigation system. Fig. (4) represents a model structure for description of variables, key factors and qualifiers in order to determine the irrigation technology and its attributed techniques (choosing the best of irrigation system for turf) under diverse physical landscape resources and situations.

\subsection{Verification, validations, and evaluation:}

The accuracy of proposed ES was tested through a sequence of steps to evaluate ES results as follows:

1. Collection of site date, parameters, and affecting factors required to select the proper irrigation system.

2. Validation was carried out to test ES logic results in particular casestudy to satisfy the requirements of irrigation engineers and owners.

3. Procedure to compare ES results in different site conditions, including extreme conditions and determine the degree of confidence by using 
proposed ES selection of proper irrigation system for different case studies.

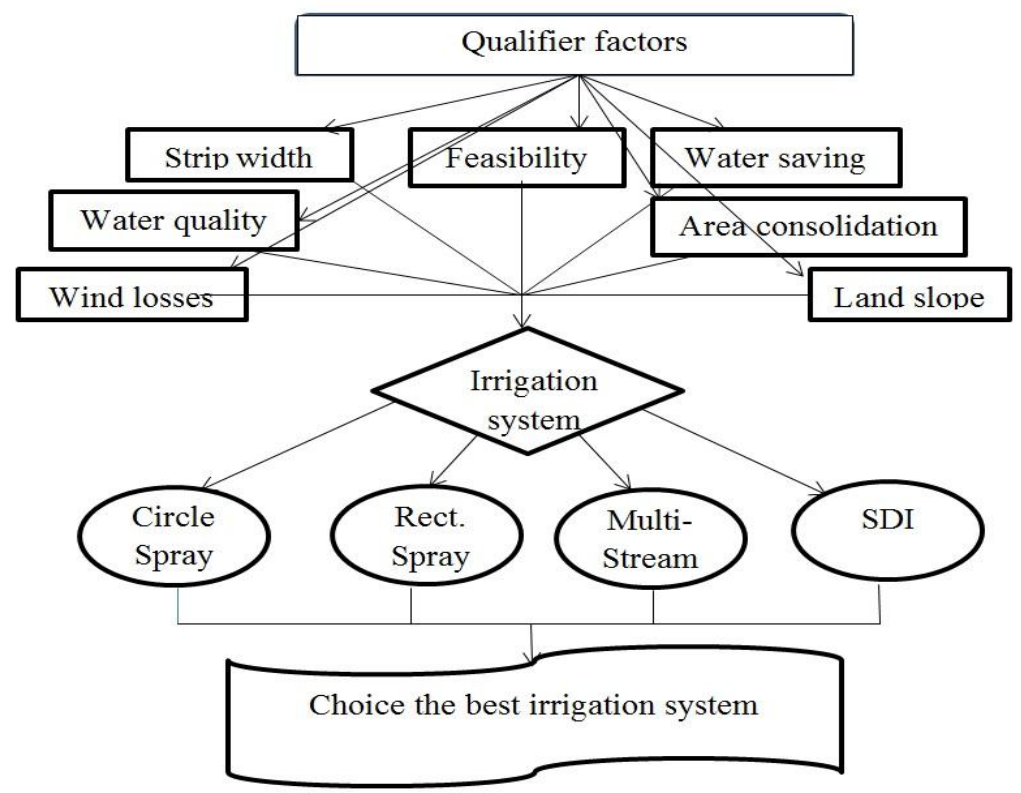

Fig.4: Diagram of factors affecting selection of proper irrigation system according to site conditions.

\section{RESULTS AND DISCUSSION}

\subsection{Proper irrigation system selection in different case studies:}

The results of testing decision table on selected case-study under investigation, in addition to software program-application on one case study, including software operation steps are discussed in the following: Figure (5) shows the weight score ratio for alternative choices of proper turf irrigation systems according to qualifier based on derived ES and actual site conditions named A, B, C, and D including wide variety of site conditions. The result shows that, in case "B", SDI system got the highest weight ratio of 4.53 with increases of $14.34 \%, 54.4 \%$, and $51.4 \%$ on Multi-stream, Rectangular spray and Circular spray, respectively, according to site conditions shown in table 2 in the "Material and Methods" section. It is clear that strip-shape factor is the most affecting factor on total score weight ratio gained for investigation, according to site condition. Case" A", illustrates weight ratio gained for irrigation systems under investigation. 


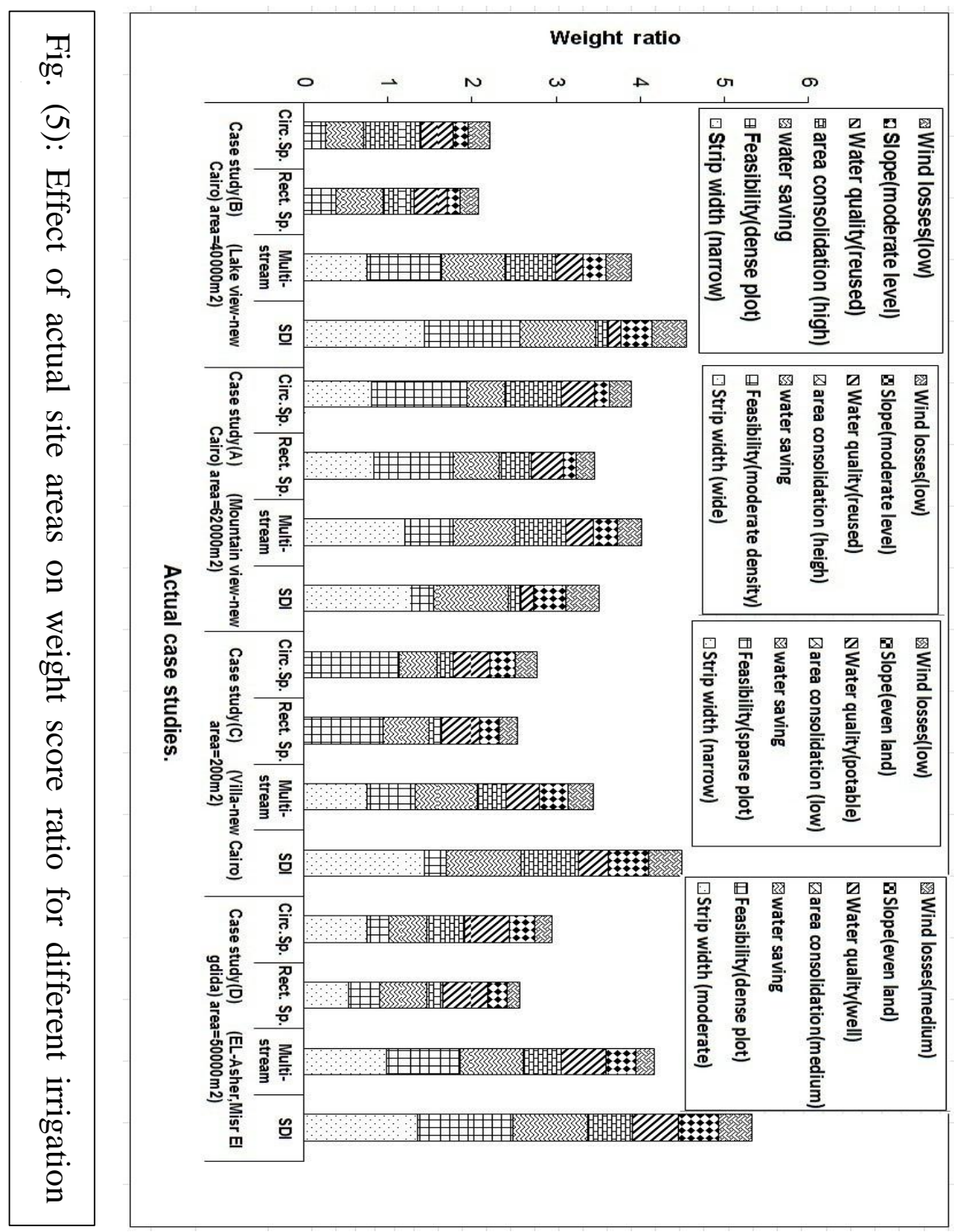

The highest weight ratio was given to Multi-stream spray with increments of $12.9 \%, 14.2 \%$, and $3.6 \%$ for SDI, Rectangular spray, and Circular spray, respectively. It is clear that SDI and rectangular spray systems were given an approximately equal weight ratio. That is due to site conditions. The most important affecting factor on total score weight, given to irrigation systems under selection, can be arranged in descending order as follows: Strip width suitability; feasibility; water saving; area consolidation; water quality; land slope and wind losses. Meanwhile, in case " $\mathrm{C}$ ", the highest weight ratio of 4.49 was given to SDI and the 
minimum of 2.53 was given to rectangular spray, according to site conditions shown in table 2 in the "Material and Methods" section. It is clear that the most affecting factor for total weight ratio goes to strip width that adds about $43.7 \%$ of total score to SDI. Case "D", shows that the highest score of 5.32 goes to SDI with an increase of $21.8 \%, 51.9 \%$, and $44.7 \%$ for Multi-stream, Rectangular spray and Circular spray, resp. according to site conditions represented in table 2 in the "Material and Methods" section. Qualifiers had equal effects on total weight ratio given to each system under investigation. Figure (6) shows the weight score ratio for alternative choices of proper turf irrigation systems, according to qualifiers based on derived ES and virtual site conditions named E and F including wide variety of site condition.

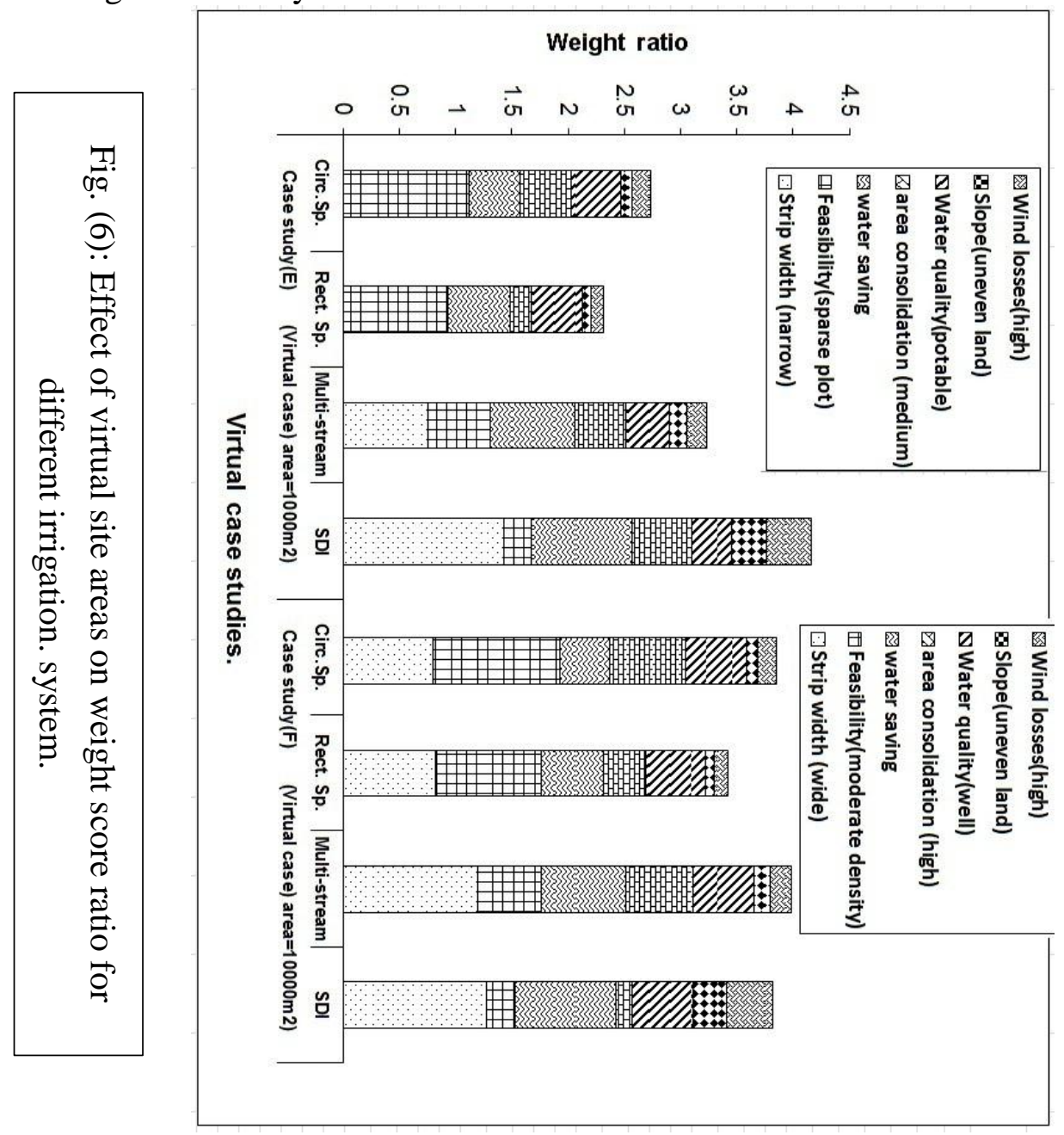


The results show that: in case "E", the SDI system recorded the highest score of 4.16 with increases of $22.35 \%, 44.23 \%$, and $34.13 \%$ over Multistream, Rectangular spray and Circular spray irrigation systems, resp., based on site conditions in table 2 in the "Material and Methods" section. It is clear that the most affecting factor on total weight ratio is with strip width with an average weight of about $31 \%$. Meanwhile, case "F", Multistream system, recorded the highest score of 3.98 with increases of $4 \%$, $14 \%$, and $4.6 \%$ over SDI, rectangular spray, and circle spray irrigation systems, resp. The factors affecting total weight ratio for irrigation system under investigation had the same effect among irrigation systems due to site conditions. Figure (7) shows that by decreasing strip width gives SDI priority among irrigation systems under investigations. For wide strip, it is clear that, multi-stream system had the second weight ratio of 1.2 after SDI with weight ratio of 1.28. Moderate strip-width for SDI gets the highest weight ratio among other alternative systems.

Figure (8) shows that for dense plot, SDI system gets the highest score, and in moderate and sparse cover, for circular spray gets the highest score. Figure (9) shows that SDI gets the highest weight ratio in low and medium categories of area consolidation. However, for high area consolidation category, Circular spray system got the highest score

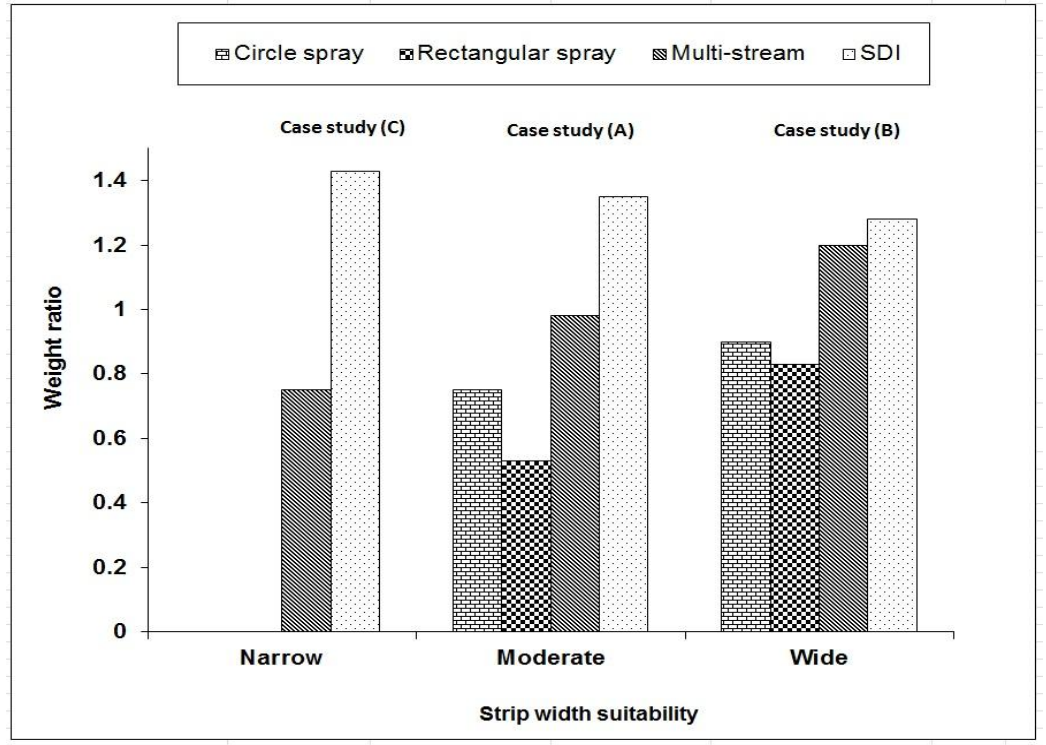

Fig. (7): Effect of suitability of strip width for irrigation systems under investigation on ES weight ratio. 


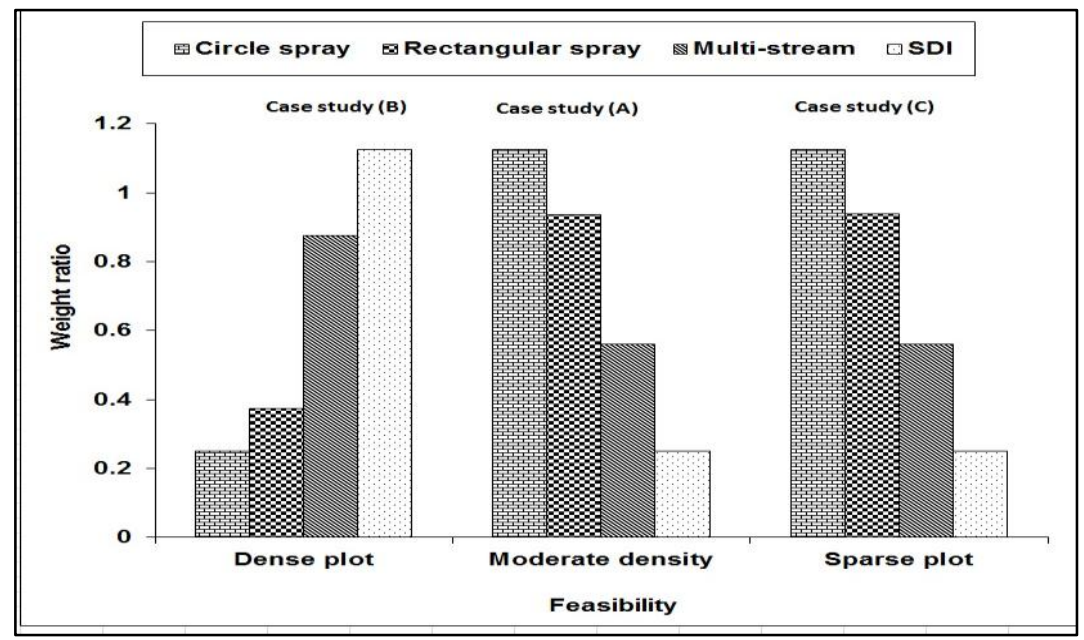

Fig. (8): Effect of quality feasibility for irrigation systems under investigation on weight ratio.

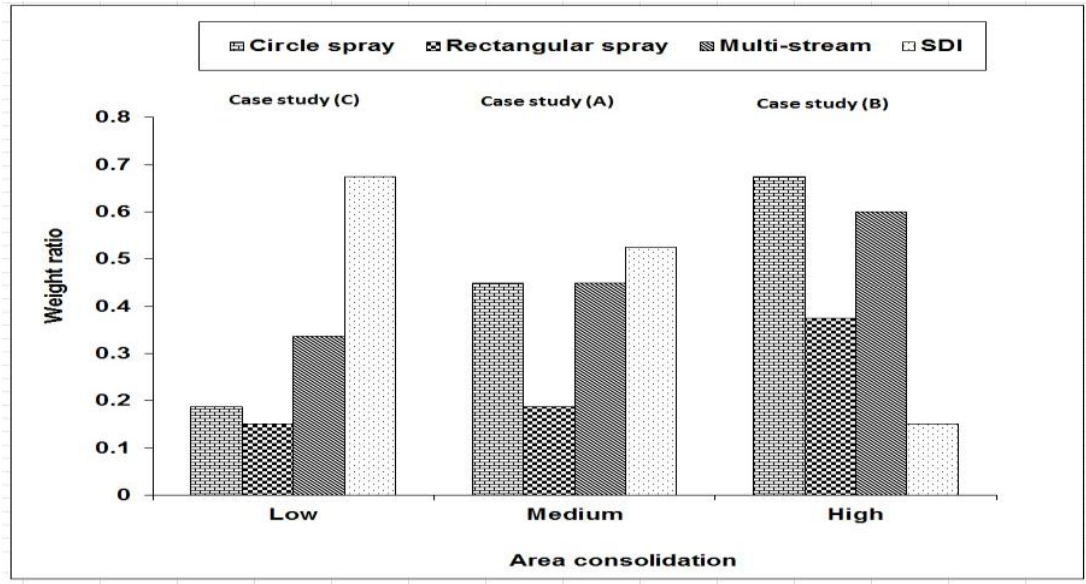

Fig. (9): Effect of area consolidation for irrigation systems under investigation on score weight ratio.

Figure (10) shows that for the best water quality all irrigation systems under investigation had the same score weight ratio. For other water qualities, the highest score goes to Circular and Rectangular spray systems.

Figure (11) shows that the highest score was given to SDI for all wind loss categories and the lowest score was given to the Rectangular spray for all wind categories. Figure (12) shows that the highest score was given to SDI for all land slope category and the lowest score was given to the Rectangular spray for all categories. It is clear that from fig. (12), that SDI gained the highest score for all land slopes and the lowest score was for Rectangular spray, for all land slopes. 


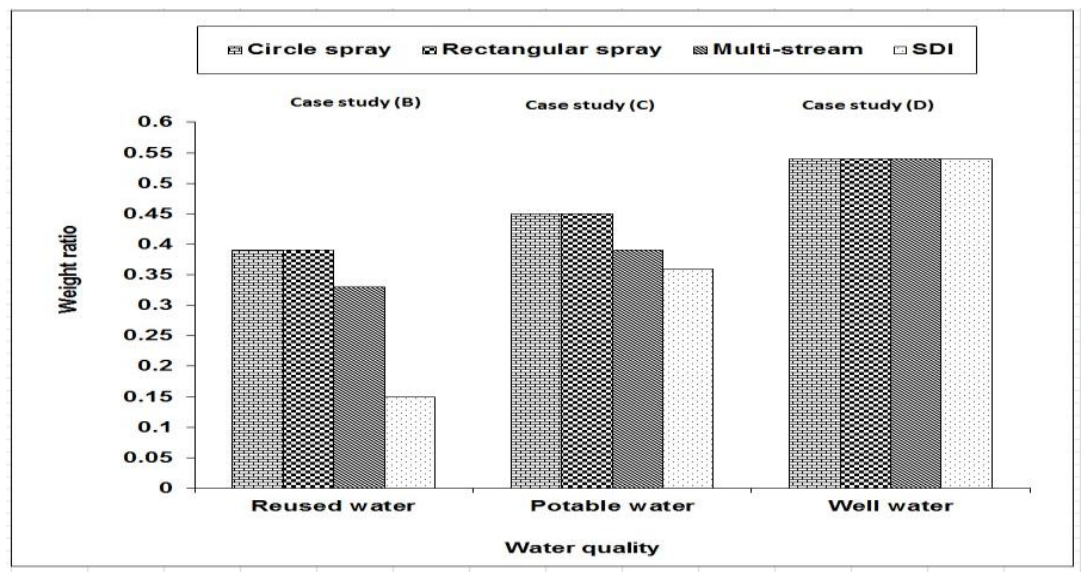

Fig.(10):Effect of water quality on score weight ratio for irrigation systems under investigation.

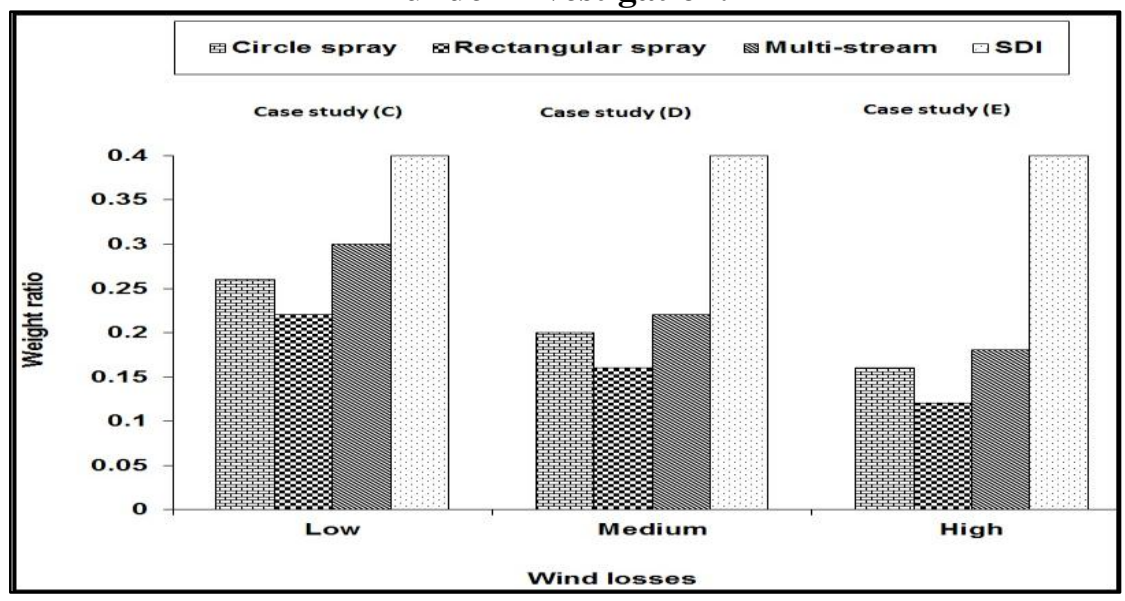

Fig. (11): Effect of wind losses on weight ratio for irrigation systems under investigation.

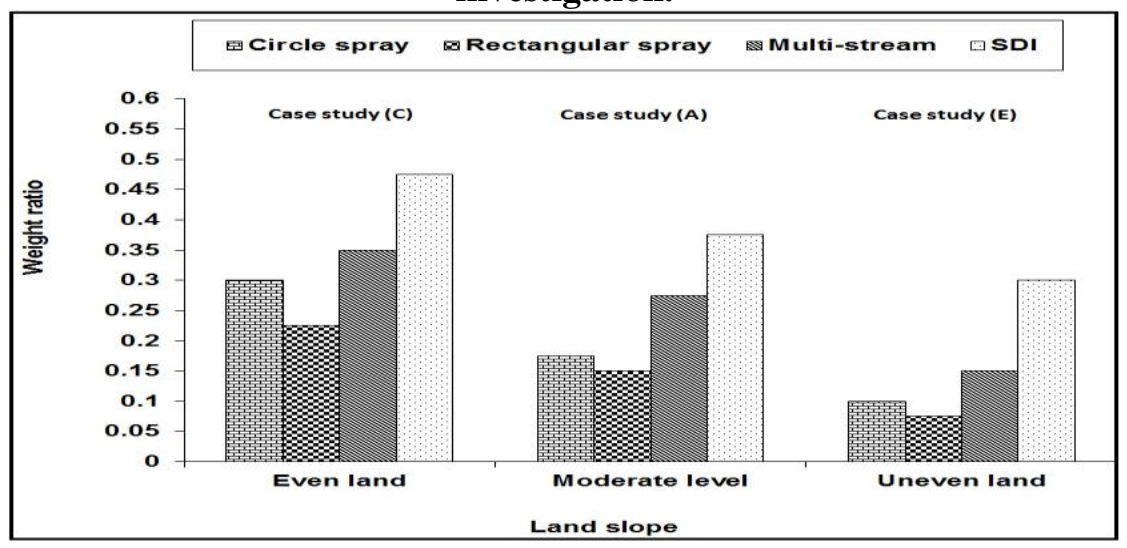

Fig.(12): Effect of land slope on weight ratio for irrigation systems under investigation. 


\subsection{ES to assist choices for turf irrigation:}

A new and simple ES was developed and tested to validate represented cases to test integrity of system. All cases were tested in the ES program. Results of representative cases are illustrated in the following. Fig. (13) shows the results of tested ES for case (C), to choose the proper irrigation system for site (c) .

\begin{tabular}{|c|c|c|}
\hline \multicolumn{2}{|c|}{ Qualifiers } & Choice \\
\hline \multicolumn{2}{|c|}{ Strip width suitability } & \multirow{4}{*}{$\begin{array}{l}\text { Add the strip width } \\
\text { suitability of turf }\end{array}$} \\
\hline$\bullet$ & Narrow & \\
\hline 0 & Moderate & \\
\hline 0 & Wide & \\
\hline \multicolumn{2}{|c|}{ Feasibilty } & \multirow{4}{*}{$\begin{array}{l}\text { Choose the } \\
\text { feasibility of quality }\end{array}$} \\
\hline$\bullet$ & Dense plot & \\
\hline 0 & Moderate density & \\
\hline 0 & Sparse plot & \\
\hline \multicolumn{2}{|c|}{ Area consolidation } & \multirow{4}{*}{$\begin{array}{l}\text { Choose the area } \\
\text { consolidation }\end{array}$} \\
\hline$\bullet$ & Low & \\
\hline 0 & Medium & \\
\hline 0 & High & \\
\hline \multicolumn{2}{|c|}{ Water quality } & \multirow{4}{*}{$\begin{array}{l}\text { Choose the water } \\
\text { quality }\end{array}$} \\
\hline 0 & Reused & \\
\hline 0 & Potable & \\
\hline 0 & Well & \\
\hline \multicolumn{2}{|c|}{ Land slope } & \multirow{4}{*}{$\begin{array}{l}\text { Choose the land } \\
\text { slope }\end{array}$} \\
\hline$\bullet$ & Even land & \\
\hline 0 & Moderate level & \\
\hline 0 & Uneven land & \\
\hline \multicolumn{2}{|c|}{ Wind losses } & \multirow{4}{*}{$\begin{array}{l}\text { Choose the wind } \\
\text { losses effect }\end{array}$} \\
\hline$\bullet$ & Low & \\
\hline 0 & Medium & \\
\hline 0 & High & \\
\hline
\end{tabular}

Fig. (13): ES inputs to the choices of the irrigation system under the stated site- conditions. 
strip width suitability narrow

Feasibility Dense Plot

Area Integration Low

Slope Run Off Even Land

Wind Losses Low

Water Quality Reused

Total Score For Circle Spray at water saving 0.45: 1.84

Total Score For rectangular spray at water saving 0.55: 1.91

Total Score For Multi Stream at water saving 0.75: 2.94

Total Score For Subsurface Drip at water saving 0.9: 5.15

\section{OK}

Fig. (14): Printout of the ES program for choice of the irrigation system under site conditions.

(Final output screen: The output takes in consideration water saving. Notice that the highest score revealed the proper irrigation system.)

\section{CONCLUSION}

Irrigation system selection for strips, green islands, and areas near buildings, sidewalks, and sloped areas is very important to obtain a good turf quality, minimum operation, installation costs and water losses. All is for the choice of the proper irrigation system in narrowly- bounded turf strip. Hereby, the aim of this investigation was to build, verify and validate an ES program for the choice in narrowly-bounded turf strips to get the best appearance and quality for different site conditions for a set of qualifying resources.Six case studies (four actual: named A, B, C, and D, in addition to two virtual cases named $\mathrm{E}$ and $\mathrm{F}$ ), including extreme site conditions, were used to test the proposed ES for the proper selection of irrigation system from alternative choices of irrigation under 
investigation.The results of proposed ES on selected case studies and "Corvid Exsys" software outcomes are discussed. Results show that the proposed ES and "Corvid Exsys" software can be efficiently used to assist proper selection of irrigation system according to site conditions and resources, including extreme conditions.

Results obtained indicate the following:

- The subsurface drip irrigation system saves water throughout the year as compared to using other irrigation systems in narrowly bounded turf strips.

- The results showed that the output of the (ES) gave high score in sub surface drip irrigation system in some case studies (B, C, and D, E) and high score in Multi-stream spray system in other case studies (A, and F).

\section{REFERENCES}

Awady, M. N., 2016. Computer applications in agricultural Engineering (In Arabic), Ch.7 on ES and their application in AE projects, Col. A. E., Azhar U., 86-100.

Corvid Exsys, Inc., 2016, Knowledge automation expert system technology, () Copyright Exsys Inc. 2011-2016, 6565 America's Parkway. NE Suite 200, Albuquerque, NM 87110 U.S.A.www.exsys.com

Devitt, D.A. and W.W. Miller, 1988. Subsurface drip irrigation of bermudagrass with saline water.Appl. Agr. Res., Vol. 3, No. 4: 133143.

Ferguson, K.R. 1994. Subsurface drip irrigation for turf. Proc. 1994 Int. Irrig. Show. Nov. 5-8.

Hillel, D. 2008. 40 Years of drip irrigation. CSA News. 53, (9): 3-7. 
Hunter, 2017. Product catalog. San Marcos, Calif.: Hunter Indust. Inc.: 48-74.

Johnson, C and B. Leinauer, 2004. Effect of salinity level and irrigation type on the establishment rate and winter survival of turfgrass.

http://www.environmentalturf.com/pdf/newmexico1.pdf. (Accessed, October 17, 2009). Atlanta, GA.

Leinauer, B. and J. Makk, 2005. Effect of irrigation type and root zone material on irrigation efficiency, Turfgrass quality, and water use on putting greens in the Southwest. USGA Turfgrass and Env. Res. Summary.

Omer, M. M.; El-Giendy, A. M. and Arafa, Y.E., 2014, Turf irrigation management under arid ecosystem condtions based on a developed expert systems, Misr. J. Agric. Eng., conf. (19):129-143.

Rain Bird. 2017. Rain Bird Landscape Irrigation Products 2016-2017 Catalog. Azusa, Calif.: Rain Bird Co.

Toro Solutions. 2006. Toro Company. Bloomington, MN.

http://toro.com/watermgmt/brochures/solutions.pdf. (Accessed October 17, 2009).

Whittaker, A. D.; D. D. Jones; R. H. Thieme and J. R. Barrett, 1987. Guidelines for getting started with expert systems, Agric. Eng., July/Aug.: 24-27.

Zoldoske, D.F.; S. Genito and G.S. Jorgenson, 1995. Subsurface drip irrigation (SDI) on turfgrass: A U. Exp. Irri. Notes: C. for Irri. Tech., Fresno, CA. 


\section{Appendix (I)}

\begin{tabular}{|c|c|c|c|}
\hline $\begin{array}{l}1 \\
2 \\
3 \\
4 \\
5 \\
6 \\
7 \\
8 \\
9 \\
10 \\
11 \\
12 \\
13 \\
14 \\
15 \\
16 \\
17 \\
18 \\
19 \\
20 \\
21 \\
22 \\
23 \\
24 \\
25 \\
26 \\
27 \\
28 \\
29 \\
30 \\
31 \\
32 \\
33 \\
34 \\
35 \\
36 \\
37 \\
38 \\
39\end{array}$ & 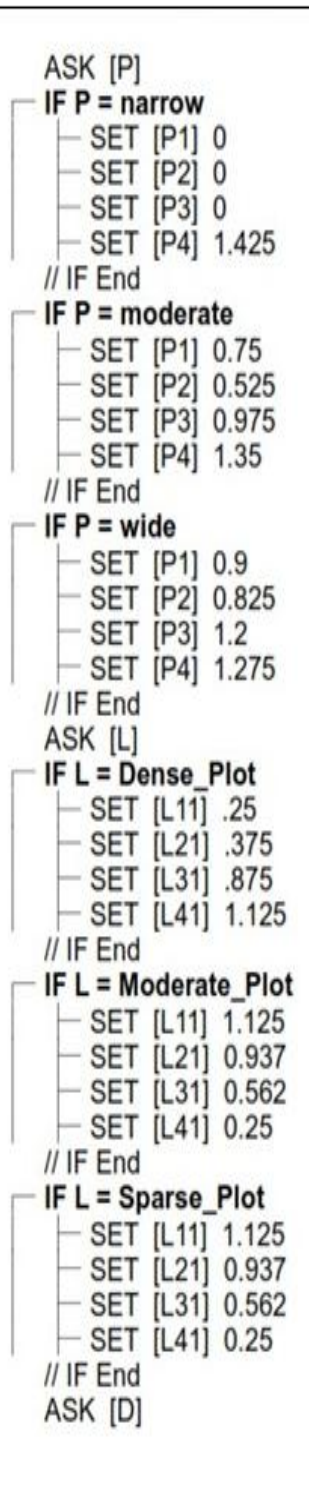 & $\begin{array}{l}40 \\
41 \\
42 \\
43 \\
44 \\
45 \\
46 \\
47 \\
48 \\
49 \\
50 \\
51 \\
52 \\
53 \\
54 \\
55 \\
56 \\
57 \\
58 \\
59 \\
60 \\
61 \\
62 \\
63 \\
64 \\
65 \\
66 \\
67 \\
68 \\
69 \\
70 \\
71 \\
72 \\
73 \\
74 \\
75 \\
76 \\
77 \\
78\end{array}$ & 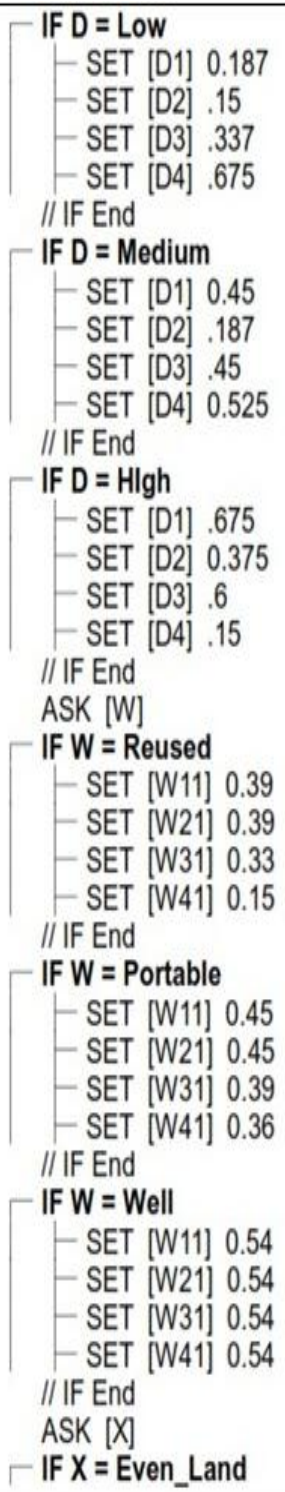 \\
\hline
\end{tabular}

Fig. (i) Program steps used to develop an ES to assist the choice of a proper irrigation system according to qualifier conditions. 


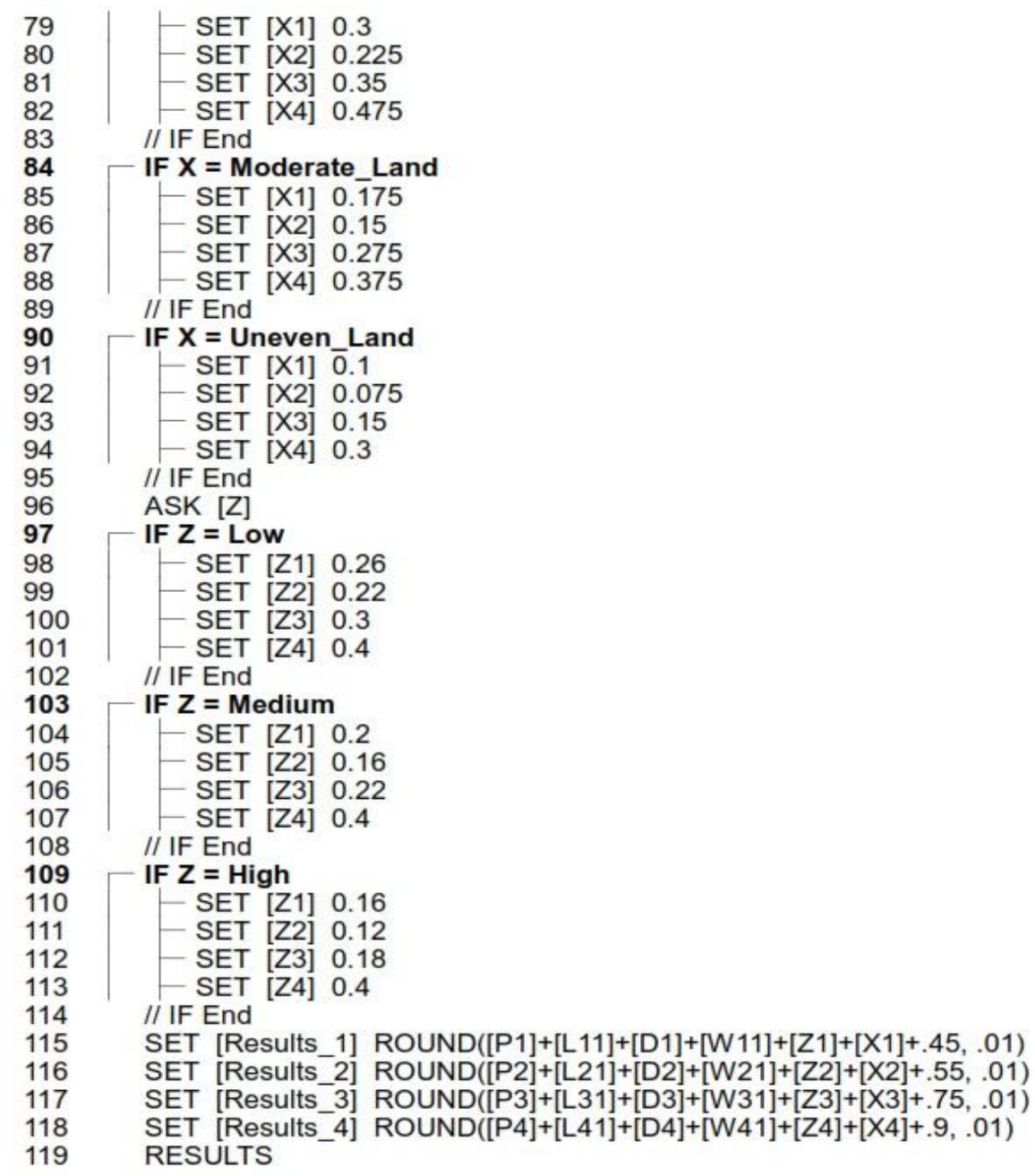

Fig.(i): Interface of "Corvid Exsys" program.

\section{الملخص العربي}

اختيار نظام ري لشرائح المسطحات الخضراء المحدودة باستخدام نظام خبير

\section{* أسامة محمد أحمد بديرت}

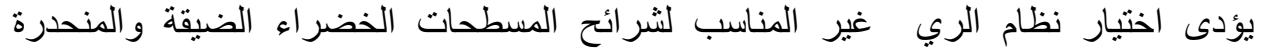
و المجاورة والجزر الى فقد كبير في المياه يصل الى •ه \% من إجمالي المياه المستخدمة لري تللك المساحات ـ لذلك يهذف البحث الى بناء نظام خبرة بالاستعانة بخبراء المجال المتخصصين

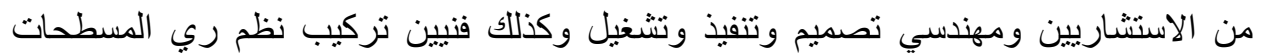
الخضر اء وللمساعدة في الاختيار المناسب لنظام ري شرائح المسطحات الخضر واء الضيقة ونئة و المنحدرة و المجاورة والجزر وفقا لظروف الأفي الموقع . 
يعتبر نظام الري بالتنقيط تحت السطحي و ونظام الري بالرش الرذاذى و الدائري والمستطيل

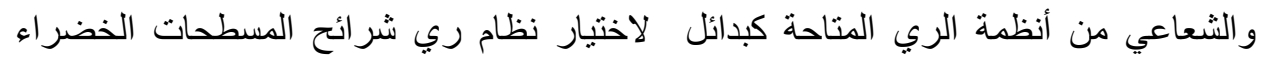

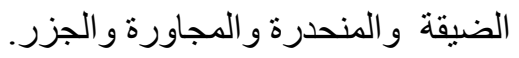

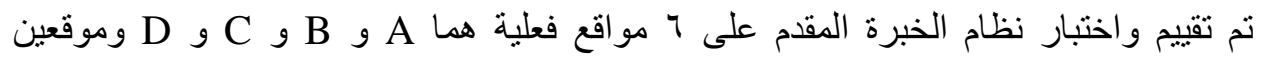
افتر اضيين هما E و F شملت كل الظروف الثنائعة و المنطرفة وذللك بالاستعانة بآر اء الخبر اء. تم تطوير برنامج حاسب الى "Corvid Exsys"، يعمل من خلال 7 "Windows 7 لتسهيل

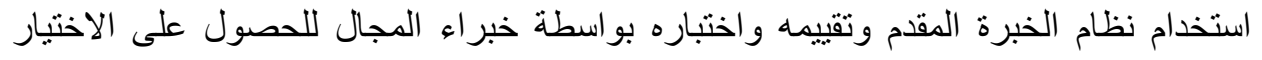
الامثل لنظام الري وفقا للظروف الحقلية.

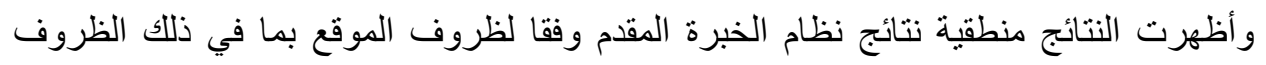

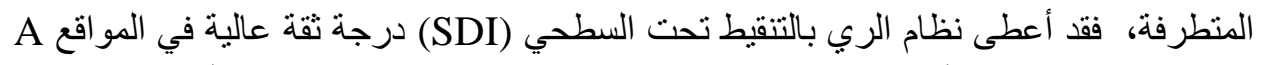

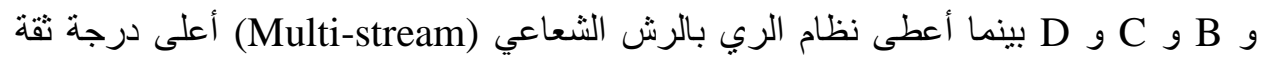
للمو اقع E و و F 